\title{
Protein hydrolysates from yeast and pig blood as alternative raw materials in microdiets for gilthead sea bream (Sparus aurata) larvae
}

\author{
Enric Gisbert ${ }^{\mathrm{a},{ }^{*}}$, Ali Skalli, ${ }^{\mathrm{a}, \mathrm{b}}$, Ignacio Fernández ${ }^{\mathrm{a}}$, Yannis Kotzamanis ${ }^{c}$, Jose Luis Zambonino-Infante ${ }^{\mathrm{d}}$, \\ Rogelio Fabregat ${ }^{\mathrm{e}}$ \\ a IRTA, Centre de Sant Carles de la Ràpita (IRTA-SCR). Ctra. Poble Nou, Km 5.5, 43540 Sant Carles de la \\ Rápita, Tarragona, Spain \\ b TECNOVIT, Tecnologia \& Vitaminas, Polígono Industrial Les Sorts, Parcela 10, 43365 Alforja, Tarragona, Spain \\ ${ }^{c}$ Hellenic Centre for Marine Research, Institute of Aquaculture, Hellinikon 16777, Athens, Greece \\ d Ifremer, PFOM Department, Fish Nutrition Laboratory, 29200 Plouzané, France \\ e PROALAN, S.A., Polígon Industrial Congost, Camí de Can Ninou, 16, 08403 Granollers, Barcelona, Spain \\ *: Corresponding author : Enric Gisbert, Tel.: + 34977745427 ; fax: + 34977744138 \\ email address : enric.gisbert@irta.cat
}

\begin{abstract}
:
In this study, we have evaluated the incorporation of two types of protein hydrolysates at 9 and $12 \%$ levels of inclusion, one from yeast (Saccharomyces cerevisiae, YPH) and another one from pig blood (PBPH), in microdiets for gilthead sea bream (Sparus aurata) larvae, and compared these results to a microdiet containing fish protein hydrolysate and another group only fed with enriched live prey (rotifers and Artemia). The trial consisted in substituting up to $75 \%$ (wt/wt) the enriched Artemia with the experimental microdiets from 15 to 40 days post-hatch, whereas larvae were exclusively fed on microdiets from 40 to $55 \mathrm{dph}$. Protein hydrolysates used in the present study were obtained from different raw materials (yeast, pig blood and fish protein concentrate) and differed in their amino acid (AA) profile and in their molecular weight distribution. YPH and PBPH were mainly composed by free amino acids (FAA) $(44 \%, \mathrm{MW}<200 \mathrm{Da})$, di- and tripeptides $(50 \%, 200<\mathrm{MW}<500 \mathrm{Da})$ and $6 \%$ of larger polypeptides $(500<\mathrm{MW}<2500 \mathrm{Da})$; whereas the fish protein hydrolysate (FPH) did only contain a minor quantity of FAA (1.5\%) and was mainly composed of di- and tripeptides (36.5\%) and larger polypeptides $(51.4 \%, 500<\mathrm{MW}<2500 \mathrm{Da})$. The contents in FAA and di- and tripeptides in the microdiet containing FPH were 0.2 and $4.4 \%$, respectively. FAA levels in microdiets including YPH and PBPH at 9 and $12 \%$ were 4.0 and $5.3 \%$, whereas levels of di- and tripeptides were 4.5 and $6.0 \%$, respectively. Results revealed that FPH in microdiets for marine fish larvae may be replaced by alternative protein hydrolysates obtained from yeast and pig blood, as fish fed with those diets performed, in terms of growth, survival, level of maturation of the enterocytes (activity of cytosolic and brush border enzymes) and incidence of skeletal deformities, as well as those larvae fed with only enriched live preys (rotifers and Artemia). Using YPH and $\mathrm{PBPH}$, the inclusion level of protein hydrolysate in microdiets might be reduced to $9 \%$ (3\% lesser to actual practices using fish protein hydrolysates) without affecting larval performance. Present results suggested the importance of leucine, valine and phenylalanine in fish larval skeletogenesis and in the appearance of skeletal disorders.
\end{abstract}

\section{Highlights}

Yeast and pig blood protein hydrolysates were tested in diets for fish larvae. The quality of fish fed on these feeds was similar to that of fish fed live prey. Deformities in fish fed these feeds were lower in comparison to a standard feed. Tested raw materials promoted gut maturation in comparison to a standard feed. Amino acids (Leu, Phe, Val) affect fish larval skeletogenesis.

Keywords: Digestive enzymes ; Larvae ; Gilthead sea bream ; Protein hydrolysate ; Skeletal deformities ; Sparus aurata 


\section{Introduction}

One of the main objectives in marine larviculture has been, for the last three decades, the replacement of live preys, normally rotifers and Artemia, by inert formulated diets (Cahu and Zambonino-Infante, 2001; Kolkowski, 2001, 2008; Engrola et al., 2009). The development of high-quality artificial microparticulate diets may potentially ameliorate water quality and overcome some disease problems, as well as reduce the high cost of live feed production, since rotifers and brine shrimp production and their enrichment procedures require of considerable space, manpower and labour. In contrast, microdiets have a high and constant nutritional value, they are easier to maintain and have lower production costs. These advantages have significant implications for the future sustainability of marine fish larvae production (Kolkovski, 2008). Although the formulation and manufacturing of microdiets have been improved during the last years and several commercial microdiets exist in the market (Holt et al., 2011), artificial diets still led to poor larval performance compared to live preys and their successful replacement has only been fully or partially achieved in a very limited number of marine fish species (Zambonino-Infante et al., 1997; Cahu and Zambonino-Infante, 2001; Koven et al., 2001; Yúfera et al., 2005; FernándezDiaz et al., 2006; Kvåle et al., 2009). One of the strategies for improving the formulation of microdiets for fish larvae is the inclusion of specific nutrients like fish protein hydrolysates that enhance the digestibility and nutritional value of the microdiet (Kolkovski, 2008).

Protein hydrolysates are promising as core materials in microdiets as they typically consist of low molecular-weight peptides resulting from protein pre-digestion, which are more likely to be absorbed by enterocytes compared to high-molecular-weight macromolecules (Önal and Langdon, 2009). In this sense, different types of experimental and commercial protein hydrolysates differing on their original raw material (i.e. casein, krill, squid, shrimp, mussel, fish meal), their production system (i.e. silage, enzymatic digestion, fermentation, among others) and their biochemical characteristics (i.e. amino acid profile, molecular weight of peptides) have shown that protein hydrolysates enhanced larval and fry growth and/or survival performance in several freshwater and marine species, such as common carp Cyprinus carpio (Carvalho et al., 1997), rainbow trout Oncorhynchus mykiss (Dabrowski et al., 2003), Atlantic salmon Salmo salar (Berge and Storebakken, 1996), European sea bass Dicentrarchus labrax (Zambonino-Infante et al., 1997; Cahu et al., 1999), Atlantic cod Gadus morhua and Atlantic halibut Hippoglossus hippoglossus (Kvåle et al., 2009). In contrast, high levels of protein hydrolysate inclusion in microdiets may not or negatively affect larval growth as it has been reported in rainbow trout (Stone et al. 1989), European sea bass (Cahu et al., 1999), turbot Scophthalmus maximus (Oliva-Teles et al., 1999), gilthead sea bream Sparus aurata (Kolkovski and Tandler, 2000), Atlantic halibut (Kvåle et al., 2002) or common carp (Carvalho et al., 2004). These studies can be hardly compared since the molecular structures of the peptidic chains of the protein hydrolysates were not always well characterized. Yet, this is a crucial factor explaining the positive role of the protein hydrolysates on larval development. Furthermore, protein hydrolysates also act as feed attractants as they contain digested protein components such as free amino acids (FAA) and peptides, thus enhancing the palatability and acceptance of the feed (Carvalho et al., 1997; Kasumyan and Døving, 2003). In addition, protein hydrolysates have been reported to likely enhance the immune response of European sea bass (Kotzamanis et al., 2007) and Atlantic halibut (Hermannsdottir et al., 2009) larvae, and to promote normal skeletogenesis (Zambonino-Infante et al., 1997).

The positive effect of the protein hydrolysates on fish larval development is well recognized nowadays, and most of commercial microdiets designed and manufactured for marine fish larvae include a moderate level of protein hydrolysate in their formulations (Holt et al., 2011); however, it is necessary to characterize the effect of each new potential raw material sources of protein hydrolysates that could be used in larval feeds. In consequence, the 
objectives of the present study were to evaluate the effects on growth performance, survival, and incidence of skeletal deformities in gilthead sea bream larvae of two new sources of protein hydrolysates, such as those obtained from yeast and pig blood replacing fish protein hydrolysates.

\section{Material and Methods}

\subsection{Experimental design, larval rearing and diets}

Newly hatched gilthead sea bream larvae were obtained from a Spanish private hatchery (Tinamenor SA, Spain) and shipped to the Institut de Recerca $i$ Tecnologia Agroalimentaries (IRTA) - Sant Carles de la Ràpita facilities. After their acclimation $(3 \mathrm{~h})$ in

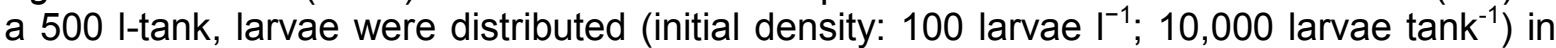
18 cylindrical fiberglass tanks $(100 \mathrm{~L})$ connected to a water recirculation unit (IRTAmar ${ }^{\circledR}$; Carbó et al., 2002). Water conditions were as follows: $18.6 \pm 0.4{ }^{\circ} \mathrm{C}, 34.5 \pm 0.5$ ppt salinity, $\mathrm{pH} 8.0 \pm 0.15$ (mean \pm SD), $20 \%$ of daily water exchange and with gently aeration and oxygenation $\left(>5 \mathrm{mg} \mathrm{l}^{-1}\right)$. Photoperiod was $12 \mathrm{~L}: 12 \mathrm{D}$, and light intensity was $500-600 \mathrm{~lx}$ at water surface.

The experimental design was conceived to study the effect of total substitution in microdiets of fish protein hydrolysate $(\mathrm{FPH}$; a fish protein concentrate obtained by grinding and enzymatic hydrolysis of fish, whole or canning byproducts, commercially named CPSP$90^{\mathrm{TM}}$, SoproPêche, France) by different sources and levels of protein hydrolysates obtained from yeast (YPH; Saccharomyces cerevisiae; NORLAN LV ${ }^{\mathrm{TM}}$; PROALAN SA, Spain) and pig blood (PBPH; NORLAN LX ${ }^{\mathrm{TM}}$; PROALAN SA, Spain), and measure their effect on growth performance, maturation of the digestive system and larval quality (incidence of skeletal deformities). As gilthead sea bream cannot be fed from the onset of exogenous feeding with inert diets, a co-feeding protocol was used to test their effects on larval performance. For this purpose, six dietary treatments in triplicate were conducted, including a standard live prey feeding regime (enriched rotifer and Artemia nauplii and metanauplii), and five co-feeding regimens differing on the type of protein hydrolysate and level of dietary inclusion ( 9 and $12 \%$ for NORLAN microdiets; and 12\% for the CPSP-90 microdiet). The levels of dietary inclusion of protein hydrolysates in microdiets were chosen according to Zambonino-Infante and Cahu (2010) recommendations. The five tested microdiets were formulated (Table 1) and prepared at the Ifremer - Fish Nutrition Laboratory facilities as described in Cahu et al. (1999).

The nutritional trial lasted for 55 days, during which enriched Artemia was substituted up to $75 \%$ (wt/wt) for the five experimental microdiets from 15 to 40 days post-hatch (dph). Since then and until the end of the study, fish were only fed with the experimental microdiets with the exception of the control group which was only fed with enriched live prey. Microdiet ingestion was confirmed by regular observation of the larval digestive tract under a binocular microscope, as microdiets in the gut were visible by transparency. However, the measurement of the microdiet intake rates was not feasible due to methodological issues (Holt et al., 2011). The feeding sequence for gilthead sea bream used in the present study was as follows: larvae were fed enriched rotifers (Brachionus plicatilis, lorica length: $178 \pm$ $30 \mu \mathrm{m}$ length) three times per day from day 3 post-hatching (dph) to $18 \mathrm{dph}$ (rotifer density was progressively increased from 5 to 10 rotifers $\mathrm{ml}^{-1}$ ). Artemia nauplii and enriched metanauplii (EG, INVE, Belgium) were offered four times per day to larvae from 16 to 20 dph $\left(0.5-0.8\right.$ nauplii $\left.\mathrm{ml}^{-1}\right)$, and enriched metanauplii from 20 to $40 \mathrm{dph}$ (2 metanauplii $\mathrm{ml}^{-}$ $\left.{ }^{1}\right)$. From $40 \mathrm{dph}$ to the end of the experiment (55 dph), larvae were only fed with the experimental diets with the exception of the live prey fed control group ( 5 metanauplii $\mathrm{ml}^{-1}$ ). Live preys were enriched with Easy Selco (INVE, Belgium) according to the manufacturer's 
instructions. Microdiets were distributed seven times per day by automatic feeders (ARVOTEC T Drum 2000TM, Arvotec, Huutokosk, Finland), at the increasing rate of 1.5 to $3.5 \mathrm{~g}$ tank $^{-1}$ day $^{-1}$ from 15 to $55 \mathrm{dph}$, which approached apparent satiation (Robin and Vincent , 2003). Excess of feed, deposited on tank bottom, was removed by daily siphoning.

\subsection{Larval growth and survival}

At 30 and $55 \mathrm{dph}$, thirty larvae were sampled from each tank and sacrificed with an overdose of anesthetic (Tricaine methanesulfonate, MS-222, Sigma). Sampled individuals were washed with distilled water to avoid marine salts and used for body size and dry weight determination. Larval standard length was measured with digital camera connected to a binocular microscope Nikon SMZ 800 using AnalySIS ${ }^{\circledR} 3.1$ (Soft Imaging Systems, $\mathrm{GmbH}$ ). Once larvae were measured in length, they were dried at $60^{\circ} \mathrm{C}$ until their weight was constant and then weighted with an analytic microbalance Sartorius BP211D. Survival rate was calculated at the end of the study as the percentage of final surviving fish in relation to the number at the beginning of the trial minus those that were sampled for different purposes.

\subsection{Analysis of skeletal deformities}

At the end of the study, sixty larvae per tank (180 per dietary regime) were sampled, killed with an overdose of anaesthetic and fixed in buffered $4 \%$ formaldehyde until they were double stained following the methodology described by Klymkowsky and Hanken (1991). In brief, specimens were rehydrated two times in distilled water during $5 \mathrm{~min}$ and then placed in alcohol $95^{\circ}$; then specimens were stained with alcian blue solution with $80 \%$ alcohol $95^{\circ}$ and $20 \%$ glacial acetic acid during $24 \mathrm{~h}$, rehydrated through a graded series of alcohol $(95 \%-25 \%)$ and macerated using a $1 \%$ aqueous solution of $\mathrm{KOH}$ with $3 \%$ hydrogen peroxide (9:1 in volume) until skeletal elements were clearly visible. Then, specimens were placed between 6 and $20 \mathrm{~h}$ in an aqueous solution saturated in sodium borate containing $0.3-0.5 \mathrm{~g}$ trypsin, and stained with alizarin red $\mathrm{S}$ (stock solution: $1 \%$ alizarin red in $1 \%$ $\mathrm{KOH}$ ) during $24 \mathrm{~h}$. Staining time was variable and depended on the size of the specimen. Finally, fish were washed with distilled water, followed by a series of baths in $1 \% \mathrm{KOH}$ to remove the excess of dye in soft tissues, and placed through graded series of glycerine$\mathrm{KOH}$ solutions. After staining, fish were placed on their right side, in order to observe meristic characters and skeletal abnormalities in the cranium, vertebral column and caudal fin complex (Fernández et al., 2008). The study was focused on the mean number of vertebra and frequency of individuals with abnormal number of vertebrae. Special emphasis was placed on the deformities occurring in the cranial region (premaxillar, maxillar and dentary), vertebral column and caudal fin complex (hypurals and parahypural, epurals, uroneural, and specialized neural arch). In particular, we calculated the frequency of individuals with lordosis, scoliosis or kyphosis, the total sum of deformities in the vertebral column, and the incidence of vertebral compression and fusion.

\subsection{Maturation of the digestive system}

The effect of experimental diets on the maturation of the digestive system was evaluated by assessing the specific activity of several pancreatic and intestinal enzymes. We measured the specific activity of two pancreatic alkaline proteases (trypsin and chymotrypsin), an intestinal cytosolic enzyme (leucine-alanine peptidase) and an intestinal brush border enzyme (alkaline phosphatase) at $55 \mathrm{dph}$, as described in Gisbert et al. (2009). 
In brief, sampled larvae $(n=50)$ from each tank were washed with distilled water and stored at $-80^{\circ} \mathrm{C}$ prior to enzyme activity analysis. All fish were dissected to separate pancreatic and intestinal segments as described by Cahu and Zambonino-Infante (1995). Pancreatic segments were homogenized (Ultra-Turrax D25 basic, IKA ${ }^{\circledR}-$ Werke) in five volumes (v/w) of ice-cold Milli-Q water, sonicated for $1.5 \mathrm{~min}\left(\mathrm{Vibra}^{-C e l l}{ }^{\circledR}\right.$, Sonics \& Materials Inc.) and centrifuged at $3,300 \mathrm{~g}(3 \mathrm{~min})$ at $4^{\circ} \mathrm{C}$. The resultant supernatant was removed for pancreatic enzyme quantification and stored at $-20^{\circ} \mathrm{C}$. For determination of intestinal enzymes, samples were homogenized in cold mannitol $50 \mathrm{mM}$, Tris- $\mathrm{HCl} 2 \mathrm{mM}$ buffer, $\mathrm{pH}$ 7.0. Prior to brush border membrane purification according to method developed by Crane et al. (1979), intestinal homogenates were sampled $(1 \mathrm{ml})$ for assessing the activity of the cytosolic leucine-alanine peptidase.

Trypsin (E.C. 3.4.21.4) activity was assayed according to Holm et al. (1988), at $25^{\circ} \mathrm{C}$ using BAPNA (N-a-benzoyl-DL-arginine p-nitroanilide) as substrate. One unit of trypsin per $\mathrm{ml}(\mathrm{U})$ was defined as $1 \mu \mathrm{mol}$ BAPNA hydrolyzed per min per $\mathrm{ml}$ of enzyme extract at $407 \mathrm{~nm}$. Chymotrypsin (EC. 3.4.21.1) activity was quantified at $25^{\circ} \mathrm{C}$ using BTEE (benzoyl tyrosine ethyl ester) as substrate in $80 \mathrm{mM}$ Tris- $\mathrm{HCl}, 100 \mathrm{mM} \mathrm{CaCl}_{2}$ buffer, $\mathrm{pH}$ 7.2. Chymotrypsin activity $(U)$ corresponded to the $\mu \mathrm{mol}$ BTEE hydrolyzed per min per ml of enzyme extract at 256nm (Worthington, 1972). The assay of a cytosolic peptidase, leucine-alanine peptidase (E.C. 3.4.11) was performed on intestinal homogenates using the method described by Nicholson and Kim (1975), using leucine-alanine as substrate in $50 \mathrm{mM}$ Tris-HCl buffer $(\mathrm{pH}$ 8.0). One unit of enzyme activity $(U)$ was defined as $1 \mathrm{nmol}$ of the hydrolyzed substrate per min per $\mathrm{ml}$ of tissue homogenate at $37^{\circ} \mathrm{C}$ and at $530 \mathrm{~nm}$. Alkaline phosphatase (E.C. 3.1.3.1) was quantified at $37^{\circ} \mathrm{C}$ using 4-nitrophenyl phosphate (PNPP) as substrate in 30 $\mathrm{mM} \mathrm{Na}{ }_{2} \mathrm{CO}_{3}$ buffer ( $\mathrm{pH}$ 9.8). One unit $(U)$ was defined as $1 \mu \mathrm{g}$ BTEE released per min per $\mathrm{ml}$ of brush border homogenate at $407 \mathrm{~nm}$ (Bessey et al., 1946). Enzyme activity was expressed as specific activity (activity units per milligram of protein, $\mathrm{U} \mathrm{mg}^{-1}$ protein). Protein content in crude tissue extracts was determined by the Bradford method (Bradford, 1976).

\subsection{Biochemical analysis of diets}

Total lipid content was quantified gravimetrically after extraction in chloroform/methanol (2:1) and evaporation of the solvent under a stream of nitrogen followed by vacuum desiccation overnight (Folch et al., 1957). Protein content $(N \times 6.25)$ was determined according to the Kjedahl's method (AOAC, 1990). Amino acids (AA) from different protein hydrolysates and microdiets were determined after acid hydrolysis $\left(6 \mathrm{~N}, 110^{\circ} \mathrm{C}, 24 \mathrm{~h}\right)$, and derivatisation by AccQ-Tag ${ }^{\circledR}$ according to the amino acid analysis application solution (Waters, USA). DL-Norvaline (Sigma) $2.5 \mathrm{mM}$ was used as an internal standard. Ultra Performance Liquid Chromatography (UPLC) analysis was performed on an Acquity system (Waters) equipped with PDA detector set at $260 \mathrm{~nm}$. The column used was BEH C18 column $(100 \times 2.1 \mathrm{~mm}$ i.d., $1.7 \mu \mathrm{m})$ from Waters. The flow rate was $0.7 \mathrm{ml} \mathrm{min}^{-1}$ and the column temperature was kept at $55^{\circ} \mathrm{C}$. Peak identification and integration was performed by the software Waters Empower 2 (Milford, MA) using an Amino Acid Standard H (Pierce, USA) as an external standard. Tryptophan was not quantified due to its susceptibility to acid hydrolysis. All chemical analyses were run in triplicate.

\subsection{Statistical analysis}

Results regarding larval performance are given as means \pm standard error (SE), while those regarding the amino acid composition of experimental microdiets are shown as mean \pm standard deviation (SD). Data expressed as percentage (survival, incidence of skeletal deformities) were previously arcsin $\left(x^{1 / 2}\right)$-transformed. Results were compared by means of One Way ANOVA (data normally distributed, Kolmogorov- Smirnov test) and when 
significant differences were detected $(P<0.05)$; the Tukey multiple-comparison test was used to detect differences amongst experimental groups (Zar, 1974).

\section{Results}

\subsection{Molecular weight distribution, amino acid profile of protein hydrolysates and microdiets}

The AA composition and molecular weight distribution of different protein hydrolysates is shown in Table 2. The three tested protein hydrolysates differed in their AA composition and levels of FAA $(<3 \%$ in the fish protein hydrolysate and $36 \%$ in the yeast and pig blood protein hydrolysates). The molecular weight distribution of the concentrated fish protein hydrolysate was different to that of protein hydrolysates from yeast and pig blood. Protein hydrolysates from yeast and pig blood were mainly composed by FAA (44\%, MW<200 Da) and di- and tripeptides $(50 \%, 200<\mathrm{MW}<500 \mathrm{Da})$, with a minor proportion in larger polypeptides $(6 \%, 500<\mathrm{MW}<2,500 \mathrm{Da})$; whereas the fish protein hydrolysate contained a minor quantity of FAA $(1.5 \%)$ and was mainly composed of di- and tripeptides $(36.5 \%)$ and larger polypeptides $(51.4 \%, 500<\mathrm{MW}<2,500 \mathrm{Da})$.

The specific AA profile of each protein hydrolysate and its level of dietary inclusion affected the final AA composition of the tested microdiets (Table 3). Regarding non-essential AA, diets containing the yeast protein hydrolysate $(9-12 \% \mathrm{YPH})$ had an excess of serine (24$26 \%$ ), proline $(22-24 \%)$ and cysteine $(67-78 \%)$, and a lesser content of glycine $(5-7 \%)$, alanine $(2-7 \%)$ and aspartic acid (1-5\%) in comparison to the FPH microdiet. Diets including the pig blood protein hydrolysate (9-12\% PBPH) contained lower levels of glycine $(10-15 \%)$ and glutamic acid $(2-7 \%)$, whereas they had a surplus in aspartic acid $(9-5 \%)$, alanine (6$3 \%)$, serine $(4-1 \%)$ and cysteine $(6 \%)$ in relation to the FPH microdiet.

Regarding essential amino acids (EAA), microdiets containing 9 and $12 \%$ of YPH were deficient in histidine (5-12\%) and lysine (1-6\%), whereas they had an excess in arginine (4$1 \%)$, threonine $(6-2 \%)$, valine $(14-11 \%)$, isoleucine $(10-7 \%)$, leucine $(6-2 \%)$ and phenylalanine $(9-5 \%)$ in comparison to the $\mathrm{FPH}$ microdiet. Microdiets containing the pig blood hydrolysate $(9-12 \% \mathrm{PBPH})$ showed lower levels in arginine (4-9\%), methionine (6$13 \%)$ and isoleucine $(5-14 \%)$ in relation to the $\mathrm{FPH}$ microdiet. The following EAA in microdiets containing the pig blood hydrolysate $(9-12 \% \mathrm{PBPH})$ were in excess with regards to the control microdiet: histidine (40-44\%), lysine (9-5\%), valine (17-13\%), leucine (14$11 \%)$ and phenylalanine (14-11\%). The rest of AA showed similar inclusion values with regards to the amino acid composition of the control microdiet.

\subsection{Larval growth and survival}

No statistically significant differences in survival rate and larval growth in terms of dry weight and standard length weight and standard length were observed among different dietary treatments at intermediate (30 dph, data not shown) and final (55 dph) sampling points (ANOVA, $P>0.05$; Table 4 ).

\subsection{Skeletal deformities}

The analysis of skeletal structures showed that different dietary treatments affected skeletogenesis and the incidence of skeletal deformities in gilthead sea bream larvae (ANOVA, $P<0.05$; Fig. 1a). The frequency of deformed fish was similar among fish fed with live preys and those fed with the protein hydrolysates obtained from yeast and pig 
blood. In particular, the total rate of skeletal abnormalities in fish fed with enriched live prey was $12.7 \pm 3.5 \%$; whereas in animals fed microdiets incorporating 9 and $12 \%$ YPH were $14.9 \pm 4.5 \%$ and $12.8 \pm 2.5 \%$, respectively; and in fish fed microdiets containing 9 and $12 \%$ PBPH was $10.5 \pm 2.0 \%$ and $14.2 \pm 3.5 \%$, respectively. Furthermore, the highest incidence of skeletal deformities was observed among those fish fed microdiets containing $12 \% \mathrm{FPH}$ $(26.3 \pm 6.8 \%)$.

Independently to the dietary treatment, cranial deformities were mainly found in the premaxilla, maxilla and dentary bones. Within those fishes with cranium deformities, $90 \%$ were pugheadness, whereas the other $10 \%$ exhibited prognathism. The frequency of fish with cranial deformities was similar among fish with fed live preys and those fed with the protein hydrolysates obtained from yeast and pig blood $(4.5 \pm 2.5 \%)$; being significantly lower than that in animals fed with $12 \%$ fish protein hydrolysates $(10.5 \pm 3.5 \%$; ANOVA, $P<$ 0.05; Fig. 1b).

Different diets did also affect the incidence of deformities along the vertebral column (lordosis, kyphosis, scoliosis and vertebral compression). In all cases, compression of two prehaemal vertebrae was the most common abnormality recorded in the vertebral column $(80 \%)$, whereas animals showing signs of scoliosis or kyphosis only represented the $15 \%$ of the total specimens with at least one deformity in their vertebral column. Considering the overall incidence of vertebral column deformities among different experimental groups, larvae fed microdiets containing 9 and $12 \% \mathrm{PBPH}$ showed the lowest incidence of deformities $(3.5 \pm 2.5 \%)$ in contrast to those fed the FPH microdiet $(7.5 \pm 3.5 \%)$. The rest of dietary treatments showed intermediate deformity values (ANOVA, $P<0.05$; Fig. 1c). Animals with fused vertebral centrums or supranumerary vertebrae were not detected in any of the dietary treatments.

Data on skeletal deformities affecting the caudal fin complex are shown in Figure $2 \mathrm{~d}$. Fusion among different hypurals and between the hypural 1 and parahypural were the most common deformity found in the fish tail from different treatments $(75 \%)$, whereas deletion or underdevelopment of the epurals and specialized neural arch were also observed (25\%). Similarly to other skeletal structures, the frequency of fish with deformities in the caudal fin complex was similar among fish fed with live preys and those fed microdiets containing $\mathrm{YPH}$ and PBPH $(7.5 \pm 3.0 \%)$, but significantly lower than that in animals fed the FPH microdiet $(15.0 \pm 4.5 \%$; ANOVA, $P<0.05)$.

\subsection{Activity of digestive enzymes}

The specific activity of the assayed pancreatic and intestinal enzymes at the end of the study is presented in Figure 2. Trypsin specific activity in gilthead sea bream larvae was similar among different dietary treatments (ANOVA, $P>0.05$; Fig. 2a). On contrary, chymotrypsin specific activity varied depending on the administered microdiet (ANOVA $P<$ 0.05; Fig. 2b). Independently of the level of dietary $\mathrm{PH}$ inclusion, gilthead sea bream fed with microdiets containing $\mathrm{YPH}$ and $\mathrm{PBPH}$ showed significantly higher values in chymotrypsin specific activity than those fed the microdiet containing $12 \% \mathrm{FPH}$. Larvae fed enriched rotifers and Artemia metanauplii showed intermediate values in chymotrypsin specific activity among the above-mentioned experimental groups.

The specific activity of alkaline phosphatase varied depending on the experimental groups (ANOVA $P<0.05$; Fig. 2c). Gilthead sea bream larvae fed microdiets containing 9 and $12 \%$ YPH and PBPH showed similar values in intestinal brush border alkaline phosphatase than those recorded in larvae fed with enriched live prey, whereas these values were significantly higher than those observed in larvae fed with the microdiet containing $12 \%$ $\mathrm{FPH}$. The specific activity of the intestinal cytosolic leucine-alanine peptidase was 
significantly affected by the diet (ANOVA, $P<0.05$; Fig. 2d). The highest values of leucinealanine peptidase were recorded in fish fed the FPH microdiet, whereas no statistically significant differences were observed among larvae fed with enriched live preys and those fed with those microdiets incorporating 9 and12\% YPH and PBPH. The ratio of alkaline phosphatase related to leucine-alanine peptidase that measured the maturation level of the intestine was significantly affected by the dietary regime (ANOVA, $P<0.05$; Fig. 2e). The above-mentioned ratio was similar among fish fed with live preys and those fed with microdiets containing $\mathrm{YPH}$ and $\mathrm{PBPH}$, whereas the ratio value in animals fed with the microdiets containing FPH was significantly lower compared to those recorded in the former groups.

\section{Discussion}

Despite of the remarkable advances in microdiet formulation for gilthead sea bream larvae (Yúfera et al., 2005; Seiliez et al., 2006; Sandel et al., 2010), larval rearing for this species still relies on co-feeding protocols, since it is still not possible to completely replace live prey by compound microdiets during early larval rearing phases (Yúfera et al., 2000, 2005; Robin and Vincent, 2003; Sandel et al., 2010). In this sense, there is still room for improving microdiet formulation and test new raw materials and feed ingredients from alternative sources for the larvae of this species. Consequently, in the present study we evaluated the inclusion of two new raw materials for formulating marine fish larval microdiets, protein hydrolysates obtained from yeast and pig blood, which are currently used in terrestrial livestock feeds, in order to evaluate their effect on gilthead sea bream larval performance. The inclusion of these dietary ingredients have been compared to a standard feeding protocol based on enriched live preys (rotifers and Artemia) and to co-feeding protocol with a microdiet containing fish protein hydrolysates, which is the most common type of protein hydrolysate used in microdiets formulated for marine fish larvae (Kolkovski, 2008). As Aragão et al. (2007) pointed out, the evaluation of an experimental microdiet with modified formulation in terms of potential growth enhancement has many constrains when working with marine fish larvae, since growth ultimately depends on several variables not only related to the characteristics of the microdiet, but also with the larval feeding behavior and digestive capacities. The above-mentioned aspects are especially relevant in the case of dietary proteins, peptides, and amino acids (Kvåle et al., 2007), and the final response can be restricted by the deficiency in other nutrient (Aragão et al., 2007; Yúfera et al., 2011). Taken into account these restrictions and experimental difficulties associated with working with microdiets, we assumed that amino acid leaching from the diet into water was minimal since larvae ingested it as soon as the feed particles touched the water surface or started to sink (personal observation), and consequently, the biochemical composition of the ingested feed was similar to that of the prepared experimental microdiet.

Protein hydrolysates from fish, yeast and pig blood used in the present study differed in their AA content and in their molecular weight distribution, and consequently, the AA profile of the manufactured microdiets was also affected by the type and level of inclusion $(9-12 \%)$ of each protein hydrolysate. The EAA profile of larval fish carcass has been proposed as a method for determining the amino acid requirements in larval fish (Yúfera et al., 2011). In this study, all five microdiets contained lower EAA levels with regards to the estimated EAA requirements calculated for gilthead sea bream larvae (Aragão et al., 2004). Dietary AA imbalances have a major impact in AA utilization by fish larvae, affecting AA oxidation and leading to decreased food conversion efficiencies, and morphophysiological disorders (Aragão et al., 2007; Yúfera et al., 2011). However, no signs of dietary deficiencies in AA were observed when comparing growth performance in gilthead sea bream larvae fed $\mathrm{FPH}$, YPH and PBPH microdiets with those from larvae fed the enriched live preys. 
It is generally recommended that artificial diets for fish larvae should have a nitrogen solubility and molecular weight profile similar to that found in live food (Carvalho et al., 2003). With regards to the molecular weight profiles of different tested protein hydrolysates, FPH contained $1.5 \%$ of FAA (MW $<200 \mathrm{Da}), 36.5 \%$ of di- and tripeptides $(200<\mathrm{MW}<500 \mathrm{Da})$ and $51.4 \%$ of larger polypeptides $(500<\mathrm{MW}<2,500 \mathrm{Da})$, whereas those from yeast $(\mathrm{YPH})$ and pig blood (PBPH) were mainly composed of $44 \%$ of FAA and $50 \%$ of di- and tripeptides. The final content in FAA and di- and tripeptides in the microdiets containing FPH was 0.2 and $4.4 \%$, respectively. The levels of FAA in microdiets including YPH and PBPH at 9 and $12 \%$ were 4.0 and $5.3 \%$, whereas levels of di- and tripeptides were 4.5 and $6.0 \%$, respectively. The molecular weight profile of the dietary hydrolysed protein fraction from the diet containing FPH differed from that reported by Carvalho et al. (2003) in rotifers and Artemia nauplii (3.3 and $6.5 \%$ of MW $<200 \mathrm{Da}, 8.3$ and $4.2 \%$ of $200<\mathrm{MW}<500$ Da and 88.4 and $89.3 \%$ of $\mathrm{MW}>500 \mathrm{Da}$, respectively), but they close in terms of large polypeptides $(\mathrm{MW}>500 \mathrm{Da})$ levels. In contrast, microdiets including YPH and PBPH showed a distribution of protein molecular sizes, mainly for FAA and di- and tripeptides, within the range of values found in live preys, which may have been advantageous in terms of feed utilization by larvae (Carvalho et al., 2003; Zambonino-Infante and Cahu, 2010). In this sense, different nutritional studies have shown that FAA seemed to improve the performance of larval fish when supplied at low levels in diets (see review in Rønnestad et al., 2003), but their excess could be detrimental as inferred from the negative results of using high dietary levels of protein hydrolysates (common carp, Carvalho et al., 1997; European sea bass, Cahu et al., 1999) and amino acid mixtures (red seabream, LópezAlvarado and Kanazawa, 1995; rainbow trout, Rodehutscord et al., 1995).

Under present experimental conditions, growth and survival rates in gilthead sea bream were similar among larvae fed with live prey and those fed with the different microdiets that differed in their level and type of protein hydrolysate. Larval performance in terms of growth and survival results obtained in this study are comparable to those already reported by Fernández et al. (2008) under the same experimental rearing conditions, and felt within the range of values already reported in other nutritional and zootechnical studies where the duration of the experiments were shorter (Robin and Vincent, 2003; Başaran et al., 2004; Robin and Peron, 2004; Seiliez et al., 2006). However, the incidence of skeletal deformities, affecting the head, vertebral column and tail, was significantly dependant on the dietary treatments containing different levels and sources of protein hydrolysates. The dietary incorporation of short peptides is beneficial for fish larval development, as promotes the harmonious development of the skeleton (see review in Cahu et al., 2003). Under present experimental conditions, larvae fed enriched live preys (rotifers and Artemia) and those fed with YPH and PBPH microdiets (9 and 12\% level of dietary inclusion) showed a lower incidence of skeletal deformities than those fed with the microdiet including $12 \% \mathrm{FPH}$. Differences in larval quality among dietary treatments may be related to enhanced proteolytic capacity of the pancreas and earlier development of the intestinal digestion in those fish fed live preys and microdiets containing YPH and PBPH (Rønnestad et al., 2003; Kvåle et al. 2009; Zambonino-Infante and Cahu, 2010), as the larval digestive tract capacity to process dietary protein is limited by proteolytic rather than by its absorptive capacity (Conceição et al., 2011). In addition, advanced intestinal digestion may have resulted in a better use of those nutrients contained in the diet that affect skeletogenesis, which might have contributed to a better development of the skeleton (Cahu et al., 2003; Lall and LewisMcCrea, 2007; Zambonino-Infante and Cahu, 2010). In addition to the molecular size of the dietary protein fraction, the AA profile may have had an effect on the quality of larvae, since dietary unbalances in AA have been reported to have major implications for larval development, other than effects on growth. In this sense, Saavedra et al. (2009) reported that a balanced dietary AA profile improved larval quality by reducing the incidence of skeletal deformities in white seabream (Diplodus sargus), whereas a diet supplemented with tyrosine and phenylalanine also improved larval quality (Saavedra et al., 2010). Under present experimental conditions, fish fed $\mathrm{YPH}$ and PBPH microdiets mainly differed to the 
FPH diet in terms of leucine, phenylalanine and valine, which were at higher levels of dietary incorporation with regards to the FPH diet. Although the exact role of these AA has not been studied in fishes with regards to skeletogenesis and bone health status, studies from higher vertebrates indicated that leucine, phenylalanine and valine were important for the proper development of the extracellular bone matrix. Thus, phenylalanine is necessary for maintaining the bone morphogenetic property of the bone matrix (Urist and Iwata, 1973), whereas leucine is the one of the main components of some structural proteoglycans that are the most abundant constituents of the non-collagenous proteins in the bone matrix (Robey, 2002). In addition, nutritional studies have shown that valine-deficient diets reduced calcium levels in bones and induced skeletal deformities in chicks (Farran and Thomas, 1992a, b). Consequently, lower levels of these three AA in the microdiet containing FPH could probably explain the higher incidence of skeletal disorders in this dietary group. However, further research on the effects of these amino acids in fish larval skeletogenesis is needed to confirm present results.

As it was pointed out before, it is generally considered that the beneficial effect of protein hydrolysates on larval development and performance might be explained by the specificities of the larval digestive physiology and the specific ability of larvae to digest and absorb short peptides (see reviews in Cahu et al., 2003; Rønnestad et al., 2003; Zambonino-Infante and Cahu, 2007). Regarding digestive enzymes, differences in chymotrypsin activity among larvae fed different diets could not be attributed to differences in the maturation level of the pancreatic function, since all groups showed similar levels of trypsin activity (Cahu and Zambonino-Infante, 1995), whereas these differences in chymotrypsin activity could be due to the type of microdiet administered to larvae. As Zambonino-Infante and Cahu (2010) reviewed, trypsin is roughly regulated by the amount of ingested diet and by dietary protein content, but not very accurately. The activity of this alkaline pancreatic protease is enhanced by non-hydrolysed protein, whereas chymotrypsin is triggered by di- and tripeptides (Zambonino-Infante et al., 1997). Thus, the absence of differences in trypsin activity between fish fed live feed versus those fed different microdiets might be explained by the fact that trypsin is poorly regulated by dietary protein levels in fish larvae (Péres et al., 1998). In contrast, differences in the peptide molecular weight distribution of the soluble protein fraction among hydrolysates obtained from fish, yeast and pig blood might explain the observed differences in chymotrypsin activity among fish fed different microdiets, since the percentage of di- and tripeptides (200-500Da MW) was different between them (Zambonino-Infante et al., 1997; Zambonino-Infante and Cahu, 2007). Regarding intestinal enzymes, microdiets containing YPH and PBPH enhanced the maturation of enterocytes compared with microdiets containing $\mathrm{FPH}$, as the activity of cytosolic (leucine-alanine peptidase) and brush border (alkaline phosphatase) enzymes revealed. In this sense, it has been previously demonstrated that such maturational changes occurred earlier when the protein fraction of the diet was constituted by a moderate level (around $20 \%$ of the dry matter) of protein hydrolysate rather than only non-hydrolysed protein (see review in Zambonino-Infante and Cahu, 2007, 2010), whereas in under present experimental conditions, only 9 and $12 \%$ of protein hydrolysate enhanced the above-mentioned maturational process in enterocytes.

In conclusion, the results from this study revealed that FPH in microdiets for marine fish larvae may be successfully substituted by protein hydrolysates from other raw materials like yeast and pig blood, as gilthead sea bream larvae fed on those diets performed, in terms of growth, survival, incidence of skeletal deformities and level of maturation of the digestive function, as well as those larvae fed only enriched live prey. Consequently, YPH and PBPH might be considered as alternative sources of protein hydrolysates for formulating marine fish larval feeds. Using YPH and $\mathrm{PBPH}$, the dietary level of protein hydrolysate inclusion in microdiets might be reduced to $9 \%$ (3\% lesser to actual practices using fish protein hydrolysates) without affecting larval performance. Present results revealed that rather than the percentage of di- and tripeptides of the dietary protein fraction, the AA profile of the 
microdiet might have had a major effect on the quality of larvae, since microdiets incorporating the three types of tested protein hydrolysates contained equivalent levels of di- and tripeptides (range: 4.4 - 6\%). These results suggested the importance of leucine, phenylalanine and valine in fish larval skeletogenesis and in the appearance of skeletal disorders.

\section{Acknowledgements}

The authors would like to express their gratitude to P. Quazuguel (IFREMER) for manufacturing the experimental microdiets and, M. Monllaó, M.S. Pimentel and J. Canoura (IRTA-SCR) for their skilled technical assistance in rearing fish larvae and producing live prey. This study was funded by the CENIT-ACUISOST project (CDTI, Spain). I.F and A.S. were supported by a predoctoral MEC (BES-2006-12650) fellowship and a postdoctoral IRTA grant, respectively.

\section{References}

Aragão, C., Conceição, L.E.C., Fyhn, H.-J., Dinis, M.T., 2004. Estimated amino acid requirements during early ontogeny in fish with different life styles: gilthead seabream (Sparus aurata) and Senegalese sole (Solea senegalensis). Aquaculture 242, 589605.

Aragão, C., Conceição, L.E.C., Lacuisse, M., Yúfera, M., Dinis, M.T., 2007. Do dietary amino acid profiles affect performance of larval gilthead seabream? Aquat. Liv. Res. $20,155-161$.

AOAC (1990). Animal Feed. In: Official Methods of Analysis of the Association of Official Analytical Chemists (Heldrich, K. ed.), pp. 684. AOAC, Arlington, VA.

Başaran, F., Muhtaroğlu, G., Ilgaz, S., Boyacıoğlu, H., 2004. The effect of tank volumes on survival of gilthead sea bream (Sparus aurata L., 1758) from hatching to the first grading in intensive culture systems. E.U. J. Fish. Aquat. Sci. 21, 69-72.

Berge, G. M., Storebakken T., 1996. Fish protein hydrolysate in starter diets for Atlantic salmon (Salmo salar) fry. Aquaculture 145, 205-212.

Bessey, O.A., Lowry, O.H., Brock, M.J., 1946. Rapid coloric method for determination of alkaline phosphatase in five cubic millimeters of serum. J. Biol. Chem. 164, 321-329.

Bradford, M.M., 1976. A rapid and sensitive method for the quantification of microgram quantities of protein utilizing the principle of protein-dye binding. Anal. Biochem. 72, 248-254.

Cahu, C. L., Zambonino-Infante, J.L., 1995. Maturation of the pancreatic and intestinal digestive functions in sea bass (Dicentrarchus labrax) effect of weaning with different protein sources. Fish Physiol. Biochem. 14, 431-437.

Cahu, C.L., Zambonino Infante, J., 2001. Substitution of live food by formulated diets in marine fish larvae. Aquaculture 200, 161-180.

Cahu, C.L., Zambonino-Infante, J.L., Quazuguel, P., Le Gall, M. M., 1999. Protein hydrolysate vs fish meal in compound diets for 10-day old sea bass Dicentrarchus labrax larvae. Aquaculture 171, 109-119.

Cahu, C., Zambonino Infante, J.L., Takeuchi, T., 2003. Nutritional components affecting skeletal development in fish larvae. Aquaculture 227, 245-258.

Carbó, R., Estévez, A., Furones, M.D., 2002. Intelligent and multifunctional recirculation system. Its Application in Research at CA-IRTA. EAS Special Publication 32, 171172.

Carvalho , A. P., Escaffre A.-M., Oliva Teles A., Bergot P., 1997. First feeding of common carp larvae on diets with high levels of protein hydrolysates. Aquacult. Int. 5, 361-367. 
Carvalho, A.P., Oliva-Teles, A., Bergot, P., 2003. Preliminary study on the molecular weight profile of soluble protein nitrogen in live food organisms for fish larvae. Aquaculture 225, 445-449.

Carvalho, A.P., Sa, R., Oliva-Teles, A., Bergot, P., 2004. Solubility and peptide profile affect the utilization of dietary protein by common carp (Cyprinus carpio) during early larval stages. Aquaculture 234, 319-333.

Conceição, L., Aragão, C., Rønnestad, I, 2011. Proteins, in: Holt, G.J. (Ed.), Larval Fish Nutrition, Wiley-Blackwell, Oxford, UK, pp. 83-116.

Crane, R.K., Boge, G., Rigal, A., 1979. Isolation of brush border membranes in vesicular form from the intestinal spiral valve of the small dogfish (Scyliorhinus canicula). Biochim. Biophys. Acta 554, 264-267.

Dabrowski, K., Lee, K.J., Rinchard, J., 2003. The smallest vertebrate, teleost fish, can utiliza synthetic dipeptide-based diets. J. Nutr. 133, 4225-4229.

Engrola, S., Figueira, L., Conceição, L.E.C., Gavaia, P.J., Ribeiro, L., Dinis, M.T., 2009. Cofeeding in Senegalese sole larvae with inert diet from mouth opening promotes growth at weaning. Aquaculture 288, 264-227.

Farran, M.T., Thomas, O.P., 1992a. Valine deficiency. 1. The effect of feeding a valinedeficient diet during the starter period on performance and feather structure of male broiler chicks. Poultry Sci. 7, 1879-1884.

Farran, M.T., Thomas, O.P., 1992b. Valine deficiency. 2. The effect of feeding a valinedeficient diet during the starter period on performance and leg abnormality of male broiler chicks. Poultry Sci. 7, 1885-1890.

Fernández-Díaz, C., Kopecka, J., Cañavate, J.P., Sarasquete, C., Solé, M., 2006. Variations on development and stress defenses in Solea senegalensis larvae fed on live and microencapsulated diets. Aquaculture 251, 573-584.

Fernández, I., Hontoria, F., Ortiz-Delgado, J.B., Kotzamanis, Y., Estévez, A., ZamboninoInfante, J.L., Gisbert, E., 2008. Larval performance and skeletal deformities in farmed gilthead sea bream (Sparus aurata) fed with graded levels of Vitamin A enriched rotifers (Brachionus plicatilis). Aquaculture 283, 102-115.

Folch, J., Lees, M., Sloane-Stanley, G.H. 1957. A simple method for the isolation and purification of total lipids from animal tissues. J. Biol. Chem. 226, 497-509.

Gisbert, E., Gimenez, G., Fernandez, I., Kotzamanis, Y., Estevez, A., 2009. Development of digestive enzymes in common dentex Dentex dentex during early ontogeny. Aquaculture 287, 381-387.

Hermannsdottir, R., Johannsdottir, J., Smaradottir, H., Sigurgisladottir, S., Gudmundsdottir, B.K., Bjornsdottir, R., 2009. Analysis of effects induced by a pollock protein hydrolysate on early development, innate immunity and the bacterial community structure of first feeding of Atlantic halibut (Hippoglossus hippoglossus L.) larvae. Fish Shellfish Immunol. 27, 595-602.

Holm, H., Hanssen, L.E., Krogdahl, A., Florholmen, J., 1988. High and low inhibitor soybean meals affect human duodenal proteinase activity differently: in vivo comparison with bovine serum albumin. J. Nutr. 118, 515-520.

Holt, C.J., Webb, K.A., Rust, M.B., 2011. Microparticulate diets: testing and evaluating success, in: Holt, G.J. (Ed.), Larval Fish Nutrition, Wiley-Blackwell, Oxford, UK, pp. 353-372.

Kasumyan, A.O., Døving, K.B., 2003. Taste preferences in fishes. Fish Fisher. 4, 259-347.

Klymkowsky, M.W., Hanken, J., 1991. Whole mount staining of Xenopus and other vertebrates. Methods Cell Biol. 36, 419-411.

Kolkovski, S. 2001. Digestive enzymes in fish larvae and juveniles - implications and applications to formulated diets. Aquaculture 200, 181-201.

Kolkovski, S., 2008. Advances in marine fish larvae diets, in: Cruz-Suárez, E., Ricque, D., Tapia, M., Nieto, M.G., Villarreal, L.D.A., Lazo, J.P., Viana, M.T. (Eds.), Avances en Nutrición Acuícola IX, Universidad Autónoma de Nuevo León, Mexico, Nuevo León, pp. 20-45. 
Kolkovski, S., Tandler, A., 2000. The use of squid protein hydrolysate as a protein source in microdiets for gilthead seabream Sparus aurata larvae. Aquac. Nutr. 6, 11-15.

Kotzamanis, Y.P., Gisbert, E., Gatesoupe, F.J., Zambonino Infante, J.L., Cahu, C., 2007. Effects of different dietary levels of fish protein hydrolysates on growth, digestive enzymes, gut microbiota, and resistance to Vibrio anguillarum in European sea bass (Dicentrarchus labrax) laevae. Comp. Biochem. Physiol., 147A, 205-214.

Koven, W., Kolkovski, S., Hadas, E., Gamsiz, K., Tandler, A., 2001. Advances in the development of microdiets for gilthead seabream, Sparus aurata: a review. Aquaculture 194, 107-121.

Kvåle, A., Harboe, T., Espe, M., Næss, T., Hamre, K., 2002. Effect of pre-digested protein on growth and survival of Atlantic halibut larvae (Hippoglossus hippoglossus L.). Aquacult. Res. 33, 311-321.

Kvåle, A., Nordgreen, A., Tonheim, S.K., Hamre, K., 2007. The problem of meeting dietary protein requirements in intensive aquaculture of marine fish, with emphasis on Atlantic halibut (Hippoglossuss hippoglossus L.). Aquac. Nutr. 13, 170-185.

Kvåle, A., Mangor-Jensen, A., Harboe, T., Hamre, K., 2009. Effects of protein hydrolysates in weaning diets to Atlantic cod (Gadus morhua L.) and Atlantic halibut (Hippoglossus hippoglossus L.). Aquac. Nutr. 15, 218-227.

Lall, S.P., Lewis-McCrea, L., 2007. Role of nutrients in skeletal metabolism and pathology in fish, an overview. Aquaculture 267, 3-19.

López-Alvarado, J., Kanazawa, A., 1995. Optimum levels of crystalline aminoacids in diets for red sea bream (Pagrus major). ICES Mar. Sci. Symp. 201, 100-105.

Nicholson, J.A., Kim, Y.S., 1975. A one-step I-amino acid oxidase assay for intestinal peptide hydrolase activity. Anal. Biochem. 63, 110-117.

Önal, U., Langdon, C., 2009. Potential delivery of water-soluble protein hydrolysates to marine suspension feeders by three different microbound particle types. Aquaculture 296, 174-178.

Oliva-Teles, A., Cerqueira, A.L., Gonçalves, P., 1999. The utilization of diets containing high levels of fish protein hydrolysate by turbot (Scophthalmus maximus) juveniles, Aquaculture 179, 195-201.

Péres, A., Zambonino-Infante, J.L., Cahu, C., 1998. Dietary regulation of activities and mRNA levels of trypsin and amylase in sea bass (Dicentrarchus labrax) larvae. Fish Physiol. Biochem. 19, 145-152.

Robey, P.G., 2002. Bone Matrix Proteoglycans and gGlycoproteins, in: Bilezikian, J.P., Raisz, L., Rodan, G.A. (Eds.), Principles of Bone Biology, $2^{\text {nd }}$ edition. Academic Press, London, UK, pp. 225-238.

Robin, J.H., Vincent, B., 2003. Microparticulate diets as first food for gilthead sea bream larva (Sparus aurata): study of fatty acid incorporation. Aquaculture 225, 463-474.

Robin, J.H., Peron, A., 2004. Consumption vs. deposition of essential fatty acids in gilthead sea bream (Sparus aurata) larvae fed semi-purified diets. Aquaculture 238, 283-294.

Rodehutscord, M., Mandel, S., Pack, M., Jacobs, S., Pfeffer, E., 1995. Free amino acids can replace protein-bound amino acids in test diets for studies in rainbow trout (Oncorhynchus mykiss). J. Nutr. 125, 956-963.

Rønnestad, I., Tonheim, S.K., Fyhn, H.J., Rojas-García, C.R., Kamisaka, Y., Koven, W., Finn, R.N., Terjesen, B.F., Barr, Y., Coincenção, L.E.C., 2003. The supply of amino acids during early feeding stages of marine fish larvae: a review of recent findings. Aquaculture 227, 147-164.

Saavedra, M., Pousao-Ferreira, P., Yúfera, M., Dinis, M. T., Conceiçao, L.E.C., 2009. A balanced amino acid diet improves Diplodus sargus larval quality and reduces nitrogen excretion. Aquac. Nutr. 15, 517-524.

Saavedra, M., Conceição, L.E.C., Barr, Y., Helland, S., Pousão-Ferreira, P., Yúfera, M., Dinis, M.T., 2010. Tyrosine and phenylalanine supplementation on Diplodus sargus larvae: effect on growth and quality. Aquac. Res. 41, 1532-1532. 
Sandel, E., Nixon, O., Lutzky, S., Ginsbourg, B., Tandler, A., Uni, Z., Koven, W., 2010. The effect of dietary phosphatidylcholine/phosphatidylinositol ratio on malformation in larvae and juvenile gilthead sea bream (Sparus aurata). Aquaculture 304, 42-48.

Seiliez, I., Bruant, J.S., Zambonino-Infante, J.L., Kaushik, S., Bergot, P., 2006. Effect of dietary phospholipid level on the development of gilthead seabream (Sparus aurata) larvae fed a compound diet. Aquac. Nutr. 12, 372-378.

Stone, F.D., Hardy, R.W., Shearer, K.D., Scott, T.M., 1989. Utilization of fish silage by rainbow trout (Salmo gairdneri). Aquaculture 76, 109-118.

Urist, M.R., Iwata, H., 1973. Preservation and biodegradation of the morphogenetic property of bone matrix, J.Theor. Biol. 38, 155-167.

Worthington Biochemical Corporation, 1972. Worthington Enzyme Manual: Enzymes, Enzyme Reagents, Related Biochemicals. Worthington Biochemical Corp., Freehold, N.J.

Yúfera, M., Fernandez-Diaz, C., Pascual, E., Sarasquete, M.C., Moyano, F.J., Diaz, M., Alarcón, F.J., Garcia-Gallego, M., Parra, G., 2000. Towards an inert diet for firstfeeding gilthead sea bream Sparus aurata L. larvae. Aquac. Nutr. 6, 143-152.

Yúfera, M., Fernández-Diaz, C., Pascual, E., 2005. Food microparticles for larval fish prepared by internal gelation. Aquaculture 248, 253-262.

Yúfera, M., Conceição, L.E.C., Battaglene, S., Fishimi, H., Kotani, R., 2011. Early development and metabolism, in: Pavlidis, M.A., Mylonas, C.C. (eds.), Sparidae: Biology and aquaculture of gilthead sea bream and other species. Blackwell Publishing Ltd., Oxford, UK, pp. 133-168.

Zambonino, J.L., Cahu, C.L., 2007. Dietary modulation of some digestive enzymes and metabolic processes in development marine fish: Applications to diet formulation. Aquaculture 268, 98-105.

Zambonino-Infante, J.L., Cahu, C.L., 2010. Effect of nutrition on marine fish development and quality, in: Koumoundouros, G. (Ed.), Recent Advances in Aquaculture Research Transworld Research Network, Kerala, India, pp. 103-124.

Zambonino-Infante, J.L., Cahu, C.L., Péres, A., 1997. Partial substitution of di- and tripeptides for native proteins in sea bass diet improves Dicentrarchus labrax larval development. J. Nutr. 127, 608-614.

Zar, J.H., 1974. Biostatistical Analysis. Prentice Hall, Inc., New Jersey, pp. 662. 
Table 1. Composition of the experimental compound microdiets containing different types and levels of protein hydrolysates.

\begin{tabular}{|c|c|c|c|c|c|}
\hline Ingredients (\% DM) & $12 \% \mathrm{FPH}$ & 9\% YPH & $12 \%$ YPH & 9\% PBPH & $12 \%$ PBPH \\
\hline Fishmeal $^{1}$ & 50 & 53 & 50 & 53 & 50 \\
\hline Fish protein hydrolysate ${ }^{2}$ & 12 & - & - & - & - \\
\hline Yeast protein hydrolysate ${ }^{3}$ & - & 9 & 12 & - & - \\
\hline Pig blood protein hydrolysate ${ }^{4}$ & - & - & - & 9 & 12 \\
\hline Fish oil $^{5}$ & 2 & 2 & 2 & 2 & 2 \\
\hline Soy lecithin ${ }^{6}$ & 20 & 20 & 20 & 20 & 20 \\
\hline Vitamin / mineral mix ${ }^{7,8}$ & $8 / 4$ & $8 / 4$ & $8 / 4$ & $8 / 4$ & $8 / 4$ \\
\hline Betaine $^{9}$ & 1 & 1 & 1 & 1 & 1 \\
\hline \multicolumn{6}{|l|}{ Proximate composition (\%) } \\
\hline Protein & 46.2 & 45.5 & 45.8 & 45.5 & 45.5 \\
\hline Lipids & 31.6 & 30.9 & 30.4 & 29.7 & 30.1 \\
\hline Ash & 14.8 & 15.0 & 14.9 & 14.3 & 14.5 \\
\hline Moisture & 7.0 & 6.9 & 6.5 & 7.0 & 6.9 \\
\hline Gross energy $(\mathrm{KJ} / \mathbf{k g})^{10}$ & 25.9 & 25.5 & 25.3 & 24.9 & 25.1 \\
\hline
\end{tabular}

*All dietary ingredients were obtained commercially: ${ }^{1}$ Fishmeal (La Lorientaise, Lorient, France) ; 77\% protein; ${ }^{2} \mathrm{CPSP}-90^{\mathrm{TM}}$ (Soluble Fish Protein Concentrate; Sopropêche, Boulogne sur Mer, France); ${ }^{3}$ NORLAN LX ${ }^{\mathrm{TM}}$ (PROALAN; Spain); ${ }^{4}$ NORLAN LV ${ }^{\mathrm{TM}}$ (PROALAN; Spain); ${ }^{5}$ fish oil (La Lorientaise, France); ${ }^{6}$ soy lecithin (Ets Louis François, St Maur des Fossés, France). Per kg vitamin mixture ${ }^{7}$ : choline concentrate $50 \%, 200 \mathrm{~g}$; vitamin E (500 Ul/g), $10 \mathrm{~g}$; vitamin D3 (500,000 Ul/g), $500 \mathrm{mg}$; vitamin B3, $1 \mathrm{~g}$; vitamin B5, $2 \mathrm{~g}$; vitamin B1, $100 \mathrm{mg}$; vitamin B2, $400 \mathrm{mg}$; vitamin B6, $300 \mathrm{mg}$; vitamin C, $20 \mathrm{~g}$; vitamin B9, $100 \mathrm{mg}$; vitamin concentrate B12 (1 g/kg), $1 \mathrm{~g}$; biotin, $1 \mathrm{~g}$; vitamin K3, $1 \mathrm{~g}$; meso-inositol, $30 \mathrm{~g}$; cellulose, 732.1 g. Per kg mineral mixture $8 \mathrm{KCl}, 90 \mathrm{~g} ; \mathrm{KIO}_{4}, 40 \mathrm{mg} ; \mathrm{CaHPO}_{4} \cdot 2 \mathrm{H}_{2} \mathrm{O}, 500 \mathrm{~g} ; \mathrm{NaCl}, 40 \mathrm{~g}$; $\mathrm{CuSO}_{4} \cdot 5 \mathrm{H}_{2} \mathrm{O}, 3 \mathrm{~g} ; \mathrm{ZnSO}_{4} \cdot 7 \mathrm{H}_{2} \mathrm{O}, 4 \mathrm{~g} ; \mathrm{CoSO}_{4} \cdot 7 \mathrm{H}_{2} \mathrm{O}, 20 \mathrm{mg} ; \mathrm{FeSO}_{4} \cdot 7 \mathrm{H}_{2} \mathrm{O}, 20 \mathrm{~g} ; \mathrm{MnSO}_{4} \cdot \mathrm{H}_{2} \mathrm{O}, 3$ g; $\mathrm{CaCO}_{3}, 215 \mathrm{~g} ; \mathrm{MgSO}_{4} \cdot 7 \mathrm{H}_{2} \mathrm{O}, 124 \mathrm{~g} ; \mathrm{NaF}, 1 \mathrm{~g} .{ }^{9}$ Betaine hydrochloride (99\%), Sigma; ${ }^{10}$ Microdiet gross energy content was estimated as : total carbohydrate $\times 17.2 \mathrm{~J} / \mathrm{kg}$; fat $\times 39.5$ $\mathrm{J} / \mathrm{kg}$; protein $\times 23.5 \mathrm{~J} / \mathrm{kg}$. 
Table 2. Amino acid composition (g AA/100 g diet) in dry weight basis and peptide molecular weight distribution (Da) of the soluble protein fraction from different dietary protein hydrolysates $(\mathrm{PH})$.

\begin{tabular}{|c|c|c|c|}
\hline Amino acid & Fish PH & Yeast PH & Pig blood PH \\
\hline Alanine & 7.6 & 3.7 & 6.5 \\
\hline Arginine & 7.2 & 5.3 & 3.4 \\
\hline Aspartic acid & 10.1 & 5.3 & 8.2 \\
\hline Cysteine & 2.2 & 2.4 & 0.8 \\
\hline Glutamic acid & 14.8 & 11.1 & 8.8 \\
\hline Glycine & 9.1 & 5.5 & 7.2 \\
\hline Histidine & 1.1 & 0.1 & 3.5 \\
\hline Isoleucine & 4.4 & 3.5 & 1.1 \\
\hline Leucine & 7.7 & 5.8 & 7.7 \\
\hline Lysine & 8.1 & 5.2 & 7.5 \\
\hline Methionine & 1.4 & 0.8 & 0.8 \\
\hline Phenylalanine & 3.6 & 3.6 & 4.0 \\
\hline Proline & 3.6 & 7.4 & 5.2 \\
\hline Serine & 4.3 & 8.3 & 4.2 \\
\hline Threonine & 4.3 & 3.4 & 3.6 \\
\hline Tyrosine & 3.0 & 1.9 & 2.0 \\
\hline Valine & 5.2 & 5.1 & 5.3 \\
\hline \multicolumn{4}{|c|}{ Peptide molecular weight ${ }^{1,2}$} \\
\hline$<200 \mathrm{Da}$ & 1.5 & 44.0 & 44.0 \\
\hline 200-500 Da & 36.5 & 50.0 & 50.0 \\
\hline $500-2,500 \mathrm{Da}$ & 51.4 & 6.0 & 6.0 \\
\hline$>2,500 \mathrm{Da}$ & 10.6 & - & - \\
\hline
\end{tabular}

${ }^{1}$ Data on the peptide molecular size distribution for fish PH $\left(\mathrm{CPSP}-90^{\mathrm{TM}}\right)$ was obtained from Kotzamanis et al. (2007). ${ }^{2}$ Data on the peptide molecular size for yeast (NORLAN LV ${ }^{\mathrm{TM}}$ ) and pig blood (NORLAN LX ${ }^{T M}$ ) hydrolysates were provided by the manufacturer. 
Table 3. Amino acid composition ( $\mathrm{g} \mathrm{AA} / 100 \mathrm{~g}$ diet) in dry weight basis of the tested microdiets containing different types and levels of protein hydrolysates. Data between brackets correspond to the percentage of variation of an $A A$ in diets containing YPH and $\mathrm{PBPH}$ with regards to that $A A$ in the microdiet including FPH. Different letters denote statistically significant differences among diets (ANOVA, $P<0.05$ ).

\begin{tabular}{|c|c|c|c|c|c|}
\hline Amino acid & $12 \%$ FPH & 9\% YPH & $12 \%$ YPH & 9\% PBPH & $12 \%$ PBPH \\
\hline Alanine & $2.70 \pm 0.007$ & $\begin{array}{c}2.64 \pm 0.004 \\
(-2.4)\end{array}$ & $\begin{array}{c}2.52 \pm 0.180 \\
(-6.7)\end{array}$ & $\begin{array}{c}2.87 \pm 0.035 \\
(6.3)\end{array}$ & $\begin{array}{c}2.79 \pm 0.011 \\
(3.3)\end{array}$ \\
\hline Arginine & $2.78 \pm 0.004 \mathrm{a}$ & $\begin{array}{c}2.88 \pm 0.001 \mathrm{a} \\
(3.8)\end{array}$ & $\begin{array}{c}2.79 \pm 0.130 \mathrm{a} \\
(0.5)\end{array}$ & $\begin{array}{c}2.67 \pm 0.035 a b \\
(-3.8)\end{array}$ & $\begin{array}{c}2.52 \pm 0.014 b \\
(-9.2)\end{array}$ \\
\hline Aspartic acid & $4.08 \pm 0.011 a b$ & $\begin{array}{c}4.08 \pm 0.025 b \\
(-1.0)\end{array}$ & $\begin{array}{c}3.86 \pm 0.150 b \\
(-5.3)\end{array}$ & $\begin{array}{c}4.43 \pm 0.049 \mathrm{a} \\
(8.7)\end{array}$ & $\begin{array}{c}4.29 \pm 0.025 \mathrm{a} \\
(5.3)\end{array}$ \\
\hline Cysteine & $0.18 \pm 0.001 \mathrm{~b}$ & $\begin{array}{c}0.30 \pm 0.001 \mathrm{a} \\
(66.7)\end{array}$ & $\begin{array}{c}0.32 \pm 0.010 \mathrm{a} \\
(77.8)\end{array}$ & $\begin{array}{c}0.19 \pm 0.001 \mathrm{~b} \\
(5.6)\end{array}$ & $\begin{array}{c}0.19 \pm 0.004 \mathrm{~b} \\
(5.6)\end{array}$ \\
\hline Glutamic acid & $6.15 \pm 0.014 a b$ & $\begin{array}{c}6.29 \pm 0.021 \mathrm{a} \\
(2.3)\end{array}$ & $\begin{array}{c}6.06 \pm 0.030 b c \\
(-1.5)\end{array}$ & $\begin{array}{c}5.71 \pm 0.067 \mathrm{c} \\
(-1.5)\end{array}$ & $\begin{array}{c}5.81 \pm 0.032 c \\
(-7.2)\end{array}$ \\
\hline Glycine & $2.78 \pm 0.007 \mathrm{a}$ & $\begin{array}{c}2.64 \pm 0.001 b \\
(-5.0)\end{array}$ & $\begin{array}{c}2.58 \pm 0.004 \mathrm{~b} \\
(-7.4)\end{array}$ & $\begin{array}{c}2.49 \pm 0.035 c \\
(-10.4)\end{array}$ & $\begin{array}{c}2.37 \pm 0.011 d \\
(-14.7)\end{array}$ \\
\hline Histidine & $0.86 \pm 0.004 b$ & $\begin{array}{c}0.82 \pm 0.004 b \\
(-4.7)\end{array}$ & $\begin{array}{c}0.76 \pm 0.094 b \\
(-11.7)\end{array}$ & $\begin{array}{c}1.20 \pm 0.011 \mathrm{a} \\
(39.8)\end{array}$ & $\begin{array}{c}1.23 \pm 0.004 \mathrm{a} \\
(43.9)\end{array}$ \\
\hline Isoleucine & $1.70 \pm 0.001 \mathrm{~b}$ & $\begin{array}{c}1.88 \pm 0.004 \mathrm{a} \\
(10.3)\end{array}$ & $\begin{array}{c}1.81 \pm 0.010 \mathrm{a} \\
(6.5)\end{array}$ & $\begin{array}{c}1.61 \pm 0.021 \mathrm{c} \\
(-5.3)\end{array}$ & $\begin{array}{c}1.57 \pm 0.007 d \\
(-13.5)\end{array}$ \\
\hline Leucine & $3.31 \pm 0.007 \mathrm{e}$ & $\begin{array}{c}3.52 \pm 0.001 \mathrm{c} \\
(6.3)\end{array}$ & $\begin{array}{c}3.39 \pm 0.020 \mathrm{~d} \\
(2.4)\end{array}$ & $\begin{array}{c}3.77 \pm 0.042 \mathrm{a} \\
(13.9)\end{array}$ & $\begin{array}{c}3.67 \pm 0.018 b \\
(10.9)\end{array}$ \\
\hline Lysine & $3.35 \pm 0.035 c$ & $\begin{array}{c}3.31 \pm 0.007 c \\
(-1.2)\end{array}$ & $\begin{array}{c}3.15 \pm 0.010 d \\
(-6.1)\end{array}$ & $\begin{array}{c}3.66 \pm 0.042 \mathrm{a} \\
(9.3)\end{array}$ & $\begin{array}{c}3.55 \pm 0.014 b \\
(5.1)\end{array}$ \\
\hline Methionine & $1.25 \pm 0.004 \mathrm{a}$ & $\begin{array}{c}1.26 \pm 0.004 \mathrm{a} \\
(0.8)\end{array}$ & $\begin{array}{c}1.18 \pm 0.004 b \\
(-5.2)\end{array}$ & $\begin{array}{c}1.18 \pm 0.011 b \\
(-5.6)\end{array}$ & $\begin{array}{c}1.08 \pm 0.007 \mathrm{c} \\
(-13.3)\end{array}$ \\
\hline Phenylalanine & $1.67 \pm 0.004 \mathrm{c}$ & $\begin{array}{c}1.82 \pm 0.004 \mathrm{~b} \\
(9.0)\end{array}$ & $\begin{array}{c}1.75 \pm 0.008 b \\
(5.1)\end{array}$ & $\begin{array}{c}1.93 \pm 0.004 \mathrm{a} \\
(13.9)\end{array}$ & $\begin{array}{c}1.88 \pm 0.007 a b \\
(10.9)\end{array}$ \\
\hline Proline & $1.81 \pm 0.007 b$ & $\begin{array}{c}2.21 \pm 0.001 \mathrm{a} \\
(22.1)\end{array}$ & $\begin{array}{c}2.25 \pm 0.010 \mathrm{a} \\
(24.0)\end{array}$ & $\begin{array}{c}1.82 \pm 0.018 b \\
(0.3)\end{array}$ & $\begin{array}{c}1.75 \pm 0.007 \mathrm{c} \\
(-3.3)\end{array}$ \\
\hline Serine & $1.95 \pm 0.007 d$ & $\begin{array}{c}2.41 \pm 0.001 \mathrm{~b} \\
(23.6)\end{array}$ & $\begin{array}{c}2.46 \pm 0.004 \mathrm{a} \\
(25.9)\end{array}$ & $\begin{array}{c}2.02 \pm 0.014 \mathrm{c} \\
(3.6)\end{array}$ & $\begin{array}{c}1.96 \pm 0.007 \mathrm{~d} \\
(0.5)\end{array}$ \\
\hline Threonine & $1.91 \pm 0.004$ & $\begin{array}{c}2.02 \pm 0.001 \\
(6.0)\end{array}$ & $\begin{array}{c}1.95 \pm 0.250 \\
(2.1)\end{array}$ & $\begin{array}{c}1.95 \pm 0.021 \\
(2.4)\end{array}$ & $\begin{array}{c}1.86 \pm 0.011 \\
(-2.4)\end{array}$ \\
\hline Tyrosine & $1.25 \pm 0.014 a b$ & $\begin{array}{c}1.31 \pm 0.004 \mathrm{a} \\
(4.4)\end{array}$ & $\begin{array}{c}1.24 \pm 0.030 a b \\
(-1.2)\end{array}$ & $\begin{array}{c}1.29 \pm 0.021 \mathrm{ab} \\
(3.2)\end{array}$ & $\begin{array}{c}1.23 \pm 0.007 b \\
(-1.6)\end{array}$ \\
\hline Valine & $2.10 \pm 0.004 c$ & $\begin{array}{c}2.39 \pm 0.004 b \\
(13.8)\end{array}$ & $\begin{array}{c}2.33 \pm 0.010 \mathrm{~b} \\
(11.0)\end{array}$ & $\begin{array}{c}2.44 \pm 0.028 \mathrm{a} \\
(16.5)\end{array}$ & $\begin{array}{c}2.36 \pm 0.007 \mathrm{~b} \\
(12.6)\end{array}$ \\
\hline
\end{tabular}

Values are shown as mean $\pm \mathrm{SD}(n=3)$. Abbreviations: FPH, fish protein concentrate obtained by grinding and enzymatic hydrolysis of fish $\left(\mathrm{CPSP}-90^{\mathrm{TM}}\right)$; YPH, protein hydrolysate obtained from yeast (NORLAN LV ${ }^{\mathrm{TM}}$ ); protein hydrolysate obtained from pig blood (NORLAN LX ${ }^{\mathrm{TM}}$ ). 
Table 4. Larval size in standard length and dry weight, and survival rate at $55 \mathrm{dph}$ of gilthead sea bream ( $S$. aurata) larvae fed microdiets containing different types and levels of protein hydrolysates.

\begin{tabular}{lccc}
\hline & Dry weight $(\mathbf{m g})$ & Standard length $(\mathbf{m m})$ & Survival (\%) \\
\hline Live prey & $16.5 \pm 1.03$ & $9.5 \pm 0.35$ & $8.5 \pm 1.16$ \\
Microdiet 12\% FPH & $16.5 \pm 1.85$ & $9.5 \pm 0.23$ & $9.8 \pm 1.62$ \\
Microdiet 9\% YPH & $14.5 \pm 1.79$ & $8.6 \pm 0.12$ & $7.9 \pm 1.79$ \\
Microdiet 12\% YPH & $14.7 \pm 1.89$ & $8.4 \pm 0.14$ & $8.4 \pm 0.98$ \\
Microdiet 9\% PBPH & $13.7 \pm 2.43$ & $10.3 \pm 0.43$ & $9.7 \pm 1.50$ \\
Microdiet 12\% PBPH & $13.2 \pm 2.06$ & $9.5 \pm 0.32$ & $10.1 \pm 1.27$ \\
\hline
\end{tabular}

Values are mean \pm SE $(n=3)$. Abbreviations: $\mathrm{FPH}$, fish protein concentrate obtained by grinding and enzymatic hydrolysis of fish (CPSP-90 ${ }^{\mathrm{TM}}$ ); $\mathrm{YPH}$, protein hydrolysate obtained from yeast (NORLAN LV'M); protein hydrolysate obtained from pig blood (NORLAN LX'M). 


\section{Figures}

Fig. 1. Incidence of skeletal deformities (mean \pm SE) in gilthead sea bream (Sparus aurata) larvae fed enriched live prey that was substituted up to $75 \%$ (wt/wt) with several experimental microdiets containing different types and levels of protein hydrolysates. Abbreviations: $\mathrm{FPH}$, concentrated fish protein hydrolysate (CPSP-90 ${ }^{\mathrm{TM}}$ ); $\mathrm{YPH}$, yeast protein hydrolysate (NORLAN LV ${ }^{\mathrm{TM}}$ ); $\mathrm{PBPH}$, pig blood protein hydrolysate (NORLAN $\left.L X^{T M}\right)$. Different letters denote statistical significant differences between dietary treatments (ANOVA, $P<0.05$ ).
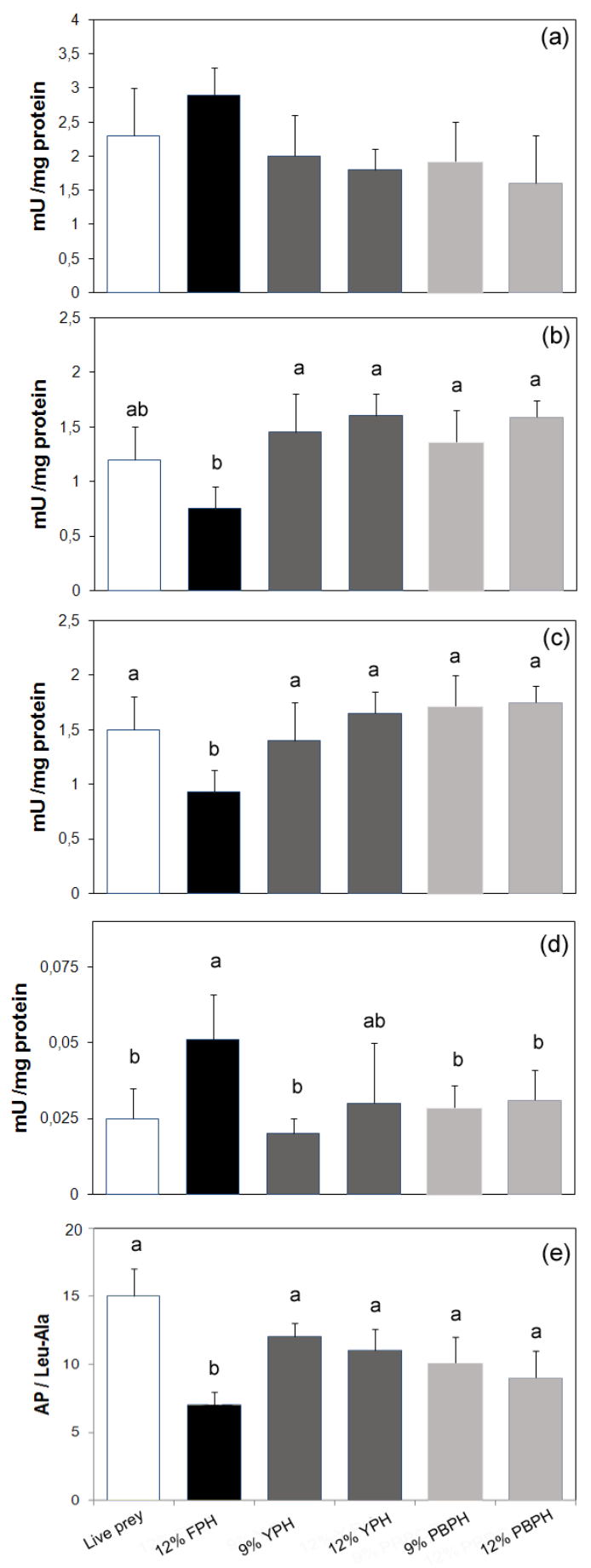
Fig. 2. Specific activity (mean \pm SE) of selected pancreatic (a, trypsin; $b$, chymotrypsin) and intestinal brush border enzymes (c, alkaline phosphatase; d, leucine-alanine peptidase; e, the ratio of alkaline phosphatase related to leucine-alanine peptidase) in gilthead sea bream (Sparus aurata) larvae fed enriched live prey that was substituted up to $75 \%$ (wt/wt) with several experimental microdiets containing different types and levels of protein hydrolysates. Abbreviations: $\mathrm{FPH}$, concentrated fish protein hydrolysate (CPSP-90 ${ }^{\mathrm{TM}}$ ); YPH, yeast protein hydrolysate (NORLAN LV ${ }^{\mathrm{TM}}$ ); PBPH, pig blood protein hydrolysate (NORLAN LX ${ }^{\mathrm{TM}}$ ). Different letters denote statistical significant differences between dietary treatments (ANOVA, $P<0.05$ ).
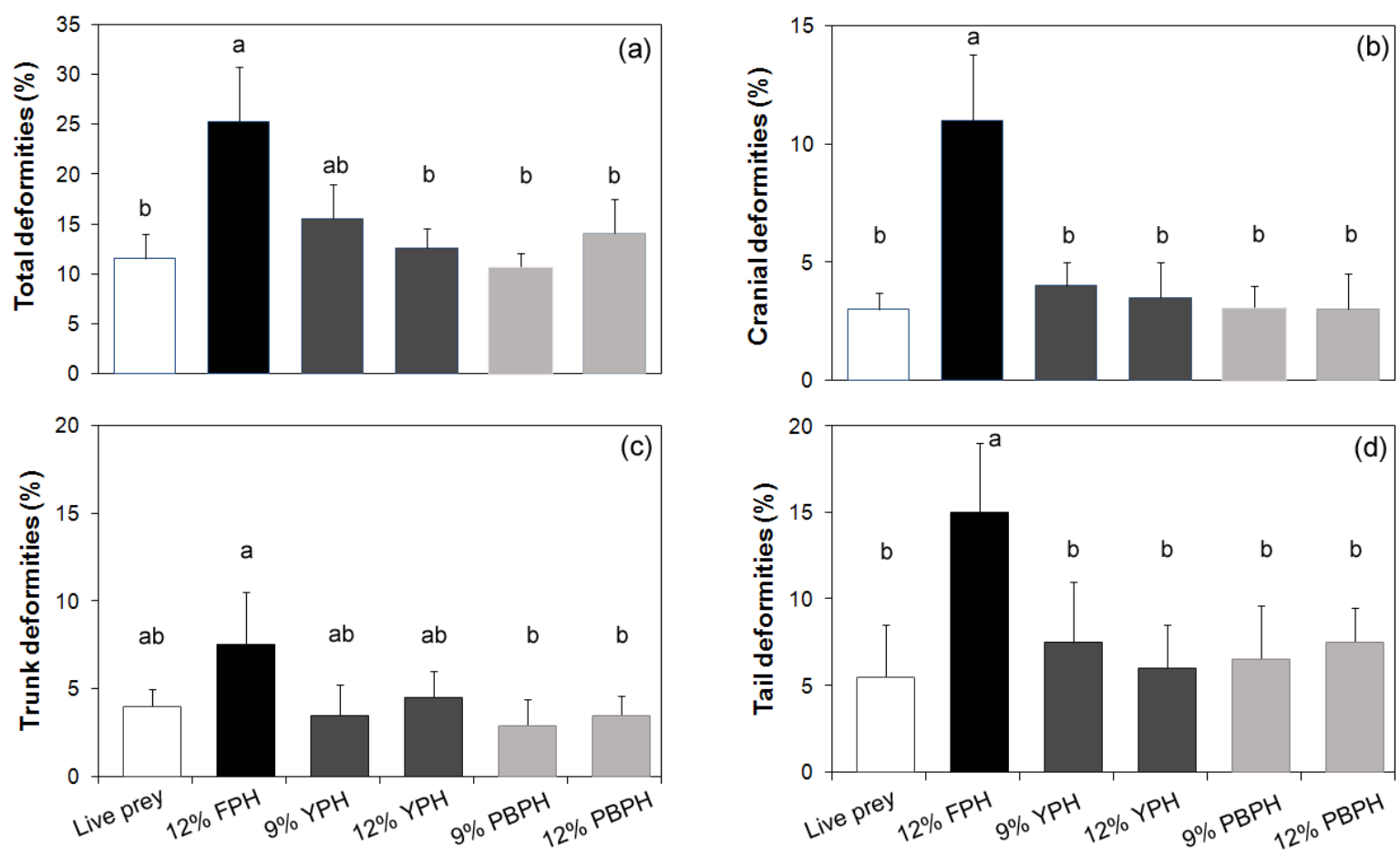